\title{
Evaluation of the antioxidant activity of Trianthema portulacastrum $\mathrm{L}$.
}

Trianthema portulacastrum L. (Aizoaceae) is historically valued as a green vegetable by poor people on the Indian Subcontinent. The plant is used in the treatment of edema in the liver and spleen, ${ }^{11}$ uteralgia, and cough. The plant is lithotriptic for the kidney and bladder. In the Indian traditional medicine system, the plant is considered as a diuretic. It has significant hepatoprotective activity against paracetamol and thio-acetamide intoxication in rats. ${ }^{[2]}$ The present investigation is to determine the antioxidant activities of the plant extract in relation to paracetamol and thioacetamide intoxication in rats.

Leaves of T. portulacastrum were collected during MarchApril 2002 from Namakkal, Tamilnadu, India and authenticated by Fr. K.M. Matthew, Director, Rapinat Herbarium, St. Joseph's College, Tiruchirapalli, Tamilnadu, India. Voucher herbarium specimens were deposited in the herbarium for future references. Coarse powder from the shade-dried leaves of $T$. portulacastrum (500 g) was extracted to exhaustion with ethanol using a soxhlet apparatus. The ethanolic extract thus obtained was dried under reduced pressure at a room temperature not exceeding $40{ }^{\circ} \mathrm{C}$.

Paracetamol was obtained from the National Medical Company, Amritsar and thioacetamide was purchased from Loba Chemie, Mumbai. 5, 5'- Dithiobis- (2-nitro benzoic acid) (DTNB), oxidized (GSSG) and reduced (GSH) glutathione, 1chloro-2, 4-dinitrobenzene (CDNB), ß-nicotinamide adenine dinucleotide phosphate, reduced form (NADPH), Bnicotinamide adenine dinucleotide, reduced form (NADH), glutathione reductase, thiobarbituric acid (TBA) and trichloroacetic acid (TCA) were purchased from Sigma Chemical Co., St. Louis. MO, USA. All the other chemicals used were either of analytical grade or of the highest purity commercially available.

Male Wistar albino rats were purchased from Perundurai Medical College, Erode and kept for a week on a commercial diet under controlled conditions (temperature $22 \pm 3{ }^{\circ} \mathrm{C}$, relative humidity $60-80 \%, 12$ h light/dark cycle with free access to food and water). Rats weighing 150-200 g were used for the experiments.

Four groups of rats, each containing six animals were used for paracetamol intoxication experiment. Group I served as control, Group II received the hepatotoxin in 50\% w/v sucrose, Group III and IV received the hepatotoxin and the ethanolic extracts of T. portulacastrum (100 and $200 \mathrm{mg} / \mathrm{kg}$, p.o) in $50 \%$ w/v sucrose, respectively.

The ethanolic extract of T. portulacastrum (100 and 200 $\mathrm{mg} / \mathrm{kg}$, p.o) which was found to be the working dose in our previous experiments, ${ }^{[2]}$ was given daily once for 10 days in succession, followed by a single administration of paracetamol ( $3 \mathrm{~g} / \mathrm{kg}$, p.o.) on the $10^{\text {th }}$ day $1 \mathrm{~h}$ after the extract administration. Similarly, another set was used for thioacetamide intoxication study. Thioacetamide was administered in $2 \%$ aqueous solution (w/v) (100 mg/kg, s.c).

The animals of the toxin control groups received vehicle daily for 10 days, followed by a single oral administration of toxicants. The normal control group received vehicle alone.

After $24 \mathrm{~h}$ of toxin administration, the rats of each group were sacrificed by cervical dislocation; blood was collected and used for estimation of reduced glutathione. The livers were dissected immediately, weighed, and homogenized. The homogenates were then centrifuged at $3200 \mathrm{X}$ for $20 \mathrm{~min}$ at 4 ${ }^{\circ} \mathrm{C}$ and the supernatant that was obtained was used for the assay of various enzymes.

The blood glutathione, superoxide dismutase (SOD), catalase (CAT) and glutathione peroxidase (GPX) were assayed by the method of Rotruck et al. ${ }^{[3]}$ Glutathione-S-tranferase (GST), glutathione reductase (GSH-R), and liver Na-K-ATPase activity were measured by the method of James et al. ${ }^{[4]}$ The concentration of TBARS (TBA reactive substances) in liver was measured using the method of Ohkawa et al. ${ }^{[5]}$

All experimental data were expressed as mean \pm SD and statistically assessed by one-way analysis of variance (ANOVA). The difference between test animals and controls was analyzed using Dunnett's test. $\mathrm{P}<0.05$ was considered significant.

The results show that pretreatment of rats with $100 \mathrm{mg}$ or $200 \mathrm{mg} / \mathrm{kg}$, p.o., of ethanolic extracts of $T$. portulacastrum prevented significantly the paracetamol- and thioacetamideinduced reduction of blood and liver glutathione, liver Na-KATPase level (Table 1). TBARS of toxicants-treated animals were significantly higher than the control animals. Administration of the ethanolic extract markedly decreased the level of TBARS. The degree of protection was more with the higher dose of the extract.

The effect of the ethanolic extract on GSH-R, GST, GPX, SOD, and CAT are shown in Table 2. Levels of these antioxidant enzymes were decreased significantly in toxicants-treated rats when compared with those of normal control animals. Treatment of rats with the extract (100 and $200 \mathrm{mg} / \mathrm{kg}$, p.o.) prevented these reductions to a large extent $(\mathrm{P}<0.001)$.

Thioacetamide is a potent hepatotoxin and carcinogen in rats. ${ }^{[6]}$ In our study, thioacetamide produced the elevation in the levels of TBARS and depletion in GSH. Pretreatment of rats with $T$. portulacastrum extract significantly reduced the elevated levels of TBARS and increased the concentration of hepatic and blood GSH. These results suggest that a higher content of GSH in blood and liver would afford the tissue a better protection against an oxidative stress.

Because the detoxification of paracetamol can be mediated by GST-catalyzed conjugation with GSH in the liver, ${ }^{[1]}$ the increased hepatic GST activity induced by the extract treatment can, therefore, reduce the acute paracetamol hepatotoxicity. 


\section{Table 1}

Effect of ethanolic extract of $T$. portulacastrum on glutathione levels in blood and liver and liver $\mathrm{Na}^{+} \mathrm{K}^{+} \mathrm{ATPase}$, and TBARS in paracetamol and thioacetamide intoxicated rats.

\begin{tabular}{|c|c|c|c|c|c|}
\hline \multirow[t]{3}{*}{ Groups } & & \multicolumn{2}{|c|}{ Glutathione } & \multirow{3}{*}{$\begin{array}{c}\text { Liver } \mathrm{Na}^{+}-\mathrm{K}^{+}-\mathrm{ATP} \text { ase } \\
\text { (U/g protein) }\end{array}$} & \multirow{3}{*}{$\begin{array}{c}\text { TBARS (nmol MDA/g of } \\
\text { wet tissue/h) }\end{array}$} \\
\hline & & \multirow[b]{2}{*}{ Blood (mg \%) } & \multirow{2}{*}{$\begin{array}{c}\text { Liver } \\
\text { (mmol/g of wet liver) }\end{array}$} & & \\
\hline & & & & & \\
\hline Normal control & & $2.05 \pm 0.04$ & $10.70 \pm 0.68$ & $10.20 \pm 0.82$ & $345.3 \pm 10.4$ \\
\hline Paracetamol control & & $0.85 \pm 0.02^{a}$ & $7.90 \pm 0.22^{\mathrm{b}}$ & $7.30 \pm 0.41^{\mathrm{b}}$ & $468.7 \pm 12.3^{a}$ \\
\hline Paracetamol + $100 \mathrm{mg} / \mathrm{kg}$ extract & & $1.44 \pm 0.03^{c}(49.1)$ & $8.80 \pm 0.31^{d}(32.1)$ & $8.96 \pm 0.63^{\mathrm{c}}(57.2)$ & $393.5 \pm 8.6^{c}(60.9)$ \\
\hline Paracetamol + $200 \mathrm{mg} / \mathrm{kg}$ extract & & $1.82 \pm 0.02^{\mathrm{c}}(80.8)$ & $9.90 \pm 0.27^{\mathrm{c}}(71.4)$ & $9.74 \pm 0.54^{\mathrm{c}}(84.1)$ & $367.8 \pm 9.7^{c}(81.7)$ \\
\hline Thioacetamide control & & $1.02 \pm 0.03^{\mathrm{a}}$ & $8.20 \pm 0.41^{b}$ & $7.82 \pm 0.37^{b}$ & $454.5 \pm 8.42^{a}$ \\
\hline Thioacetamide +100 mg/kg extract & & $1.64 \pm 0.08^{c}(60.1)$ & $9.10 \pm 0.38^{d}(36)$ & $8.75 \pm 0.68^{c}(39)$ & $394.7 \pm 9.15^{c}(54.7)$ \\
\hline Thioacetamide $+200 \mathrm{mg} / \mathrm{kg}$ extract & & $1.98 \pm 0.06^{c}(93.2)$ & $9.80 \pm 0.31^{c}(64)$ & $9.54 \pm 0.74^{c}(72.2)$ & $369.5 \pm 10.28^{c}(77.8)$ \\
\hline One-way & $\mathrm{F}$ & 60.2 & 43.5 & 42.8 & 25.2 \\
\hline \multirow[t]{2}{*}{ ANOVA } & df & 6,36 & 6,36 & 6,36 & 6,36 \\
\hline & $\mathrm{P}$ & 0.01 & 0.01 & 0.01 & 0.01 \\
\hline
\end{tabular}

Values are mean $\pm S D ; n=6$ animals per group. Values in the parenthesis indicate percentage protection provided by the extract in individual biochemical parameters from their elevated values. The percentage of protection is calculated as $100 \mathrm{X}$ (values of toxicant control values of sample) / (values of toxicant control values of control). aP $<0.001$ when compared with normal control; ${ }^{b} \mathrm{P}<0.01$ when compared with normal control. ${ }^{\mathrm{c}} \mathrm{P}<0.001$ when compared with paracetamol control; ${ }^{\mathrm{d}} \mathrm{P}<0.01$ when compared with paracetamol control.

Table 2

Effect of ethanolic extract of T. portulacastrum on GSH-R, GSH-PX, GST, SOD and CAT in paracetamol and thioacetamide intoxicated rats.

\begin{tabular}{|c|c|c|c|c|c|}
\hline Group & $\begin{array}{c}\text { GSH-R } \\
\text { ( } \mu \mathrm{mol} \text { NADPH/ } \\
\text { min/g of wet liver) }\end{array}$ & $\begin{array}{c}\text { GSH-PX } \\
\text { (U/mg protein) }\end{array}$ & $\begin{array}{c}\text { GST } \\
\text { (U/g of wet liver) }\end{array}$ & $\begin{array}{c}S O D \\
\text { (U/mg protein) }\end{array}$ & $\begin{array}{c}\mathrm{CAT} \\
\left(\mathrm{H}_{2} \mathrm{O}_{2} \text { decomposed/ }\right. \\
\mathrm{min} / \mathrm{mg} \text { protein })\end{array}$ \\
\hline Normal Control & $165.7 \pm 3.8$ & $10.2 \pm 0.82$ & $104.5 \pm 1.9$ & $9.82 \pm 0.32$ & $72.6 \pm 2.5$ \\
\hline Paracetamol control & $102.3 \pm 4.5^{\mathrm{a}}$ & $6.80 \pm 0.64^{b}$ & $89.6 \pm 2.1^{\mathrm{b}}$ & $5.56 \pm 1.04^{\mathrm{a}}$ & $39.87 \pm 2.42^{\mathrm{a}}$ \\
\hline Paracetamol + $100 \mathrm{mg} / \mathrm{kg}$ extract & $145.8 \pm 5.4^{c}(68.2)$ & $8.43 \pm 0.54^{d}(47.2)$ & $94.3 \pm 0.9^{\circ}(31.5)$ & $8.21 \pm 0.78^{c}(62.2)$ & $58.72 \pm 3.18^{\mathrm{c}}(57.5)$ \\
\hline Paracetamol + $200 \mathrm{mg} / \mathrm{kg}$ extract & $160.5 \pm 7.2^{\mathrm{c}}(91.7)$ & $9.20 \pm 0.38^{c}(69.5)$ & $98.1 \pm 1.7^{\circ}(63.7)$ & $9.15 \pm 0.72^{\mathrm{c}}(84.2)$ & $64.52 \pm 2.74_{c}(75.1)$ \\
\hline Thioacetamide $+200 \mathrm{mg} / \mathrm{kg}$ extract & $159.3 \pm 5.2^{\mathrm{c}}(88.9)$ & $9.6 \pm 0.65^{\circ}(78.6)$ & $98.4 \pm 1.9^{d}(69)$ & $9.30 \pm 0.27^{c}(86.6)$ & $69.1 \pm 2.4^{c}(88.1)$ \\
\hline One-way & 78.5 & 69.5 & 43.2 & 35.6 & 14.5 \\
\hline \multirow[t]{2}{*}{ ANOVA } & 6,36 & 6,36 & 6,36 & 6,36 & 6,36 \\
\hline & 0.01 & 0.01 & 0.01 & 0.01 & 0.01 \\
\hline
\end{tabular}

Values are mean $\pm S . D ; n=6$ animals per group. Values in the parenthesis indicate percentage protection provided by the extract in individual biochemical parameters from their elevated values caused by the hepatoprotection. The percentage of protection is calculated as in Table 1 . ${ }^{\mathrm{P} P}<0.001$ when compared with normal control; ${ }^{\mathrm{b}} \mathrm{P}<0.01$ when compared with normal control. ${ }^{\mathrm{c}} \mathrm{P}<0.001$ when compared with thioacetamide control; ${ }^{\mathrm{d}} \mathrm{P}<0.01$ when compared with thioacetamide control.

GSH-R is a family of cytosolic hepatic enzymes involved in the detoxification of a range of xenobiotic compounds by their conjugation with GSH. ${ }^{[8]}$ It has been reported that paracetamol produces an increased blood GSH-R activity, which occurs at a maximum of $24 \mathrm{~h}$ after administration. Pretreatment of T. Portulacastrum significantly reduced GSH-R in toxicant-administered rats

The activities of $\mathrm{Na}^{+} \mathrm{K}^{+}$ATPase, SOD, and CAT were decreased $(\mathrm{P}<0.001)$ in hepatotoxin-treated animals. ${ }^{[9]}$ The extract may be useful for the prevention of hepatotoxin-induced liver damage. These findings show that the antioxidant capac- ity of the liver decreased leading to the generation of lipid peroxides resulting in liver damage. Ethanolic extract of the plant increases the activity of SOD and CAT and it scavenges free radicals and reduces hepatic damage. These results suggest that the hepatoprotective action of the extract might be due to its antioxidant activity.

In conclusion, the hepatoprotective effect of $T$. portulacastrum alcohol extract against paracetamol- and thioacetamide-induced hepatotoxicity in rats appears to be related to the inhibition of lipid peroxidative processes and to the prevention of GSH depletion. 


\section{G. Kumar, G.S. Banu*, M.R. Pandian*}

Department of Biochemistry, Selvam Arts \& Science College, Namakkal and *Centre for Biotechnology, Muthayammal College of Arts and Sciences, Kakkaveri, Rasipuram, Namakkal, Tamilnadu, India. E-mail: rajamoses@yahoo.com.

\section{References}

1. Javed Ahmad, Farooqui $A H$, Sageer Ahmad. Trianthema portulacastrum $L$ an herbal drug for the cure of edema. J Herbs Spices and Med plants 2000;7:6570.

2. Kumar G, Sharmila Banu G, Vanitha Pappa P, Sundararajan M, Rajasekara Pandian M. Hepatoprotective activity of Trianthema portulacastrum $L$ against paracetamol and thioacetamide intoxication in albino rats. J Ethnopharmacol
2004; 92: 37-40.

3. Rotruck J, Pope A, Ganther H, Swanson A. Selenium: Biochemical roles as a component of glutathione peroxidase. Science 1973;179:588-90.

4. James N, Gay R, Hill R. Influence of estrogen on glutathione levels and glutathione metabolizing enzymes in uteri and R3230 AC mammary tumors of rats. Biochem Biophys Acta 1980;630:485-96.

5. Ohkawa H, Ohishi N, Yagi K. Assay of lipid peroxidation in animal tissues by thiobarbutiric acid reaction. Anal Biochem 1979;95:351-58.

6. Fitzhugh $\mathrm{OG}$, Nelson, AA. Liver tumors in rats fed thiourea or thioacetamide. Science 1948;108:626-8.

7. Threlkeld D. CNS drugs. Acetaminophen. In: Facts and comparisons drug informations. St.Louis, MO: 1997.

8. Eaton DL, Bammler TK. Concise review of Glutathione-S-transferases and their significance to toxicology. Toxicol Sci 1999;49:156-64.

9. Chattopadhyay RR. Possible mechanism of hepatoprotective activity of Azadirachta indica leaf extract: Part II. J Ethnopharmacol 2003;89:217- 9.

\section{INTERNATIONAL SYMPOSIUM ON “ADVANCES IN RESEARCH ON NEURODEGENERATIVE DISEASES”

ANNUAL MEETING OF THE SOCIETY OF NEUROCHEMISTRY INDIA (SNCI)

Date : December $16-17^{\text {th }}, 2005$

Venue : Dr. ALM. PGIBMS, University of Madras, Taramani, Chennai-600 113.

Pre-symposium : Workshop on Neurochemical Techniques, $\left(6-15^{\text {th }}\right.$, Dec 2005)

\section{Contact:}

Prof. S.L. MAHESWARI

Organizing Secretary,

Department of Pharmacology and Environmental Toxicology,

Dr. ALM. PGIBMS, University of Madras, Taramani, Chennai-600 113,

E-mail: snci2005@rediffmail.com; Website: www.snci2005chennai.com 